\begin{tabular}{|l|}
\hline Удосконалено узгоджене управлін- \\
ня електроспоживанням дробарно-зба- \\
гачувального комплексу підприємства. \\
Розроблено алгоритм управління підпри- \\
ємством у періоди обмежень потужності \\
енергосистеми. Зменшення питомихенер- \\
говитрат досягнуто управлінням елек- \\
троспоживанням дробарної та збагачу- \\
вальноїфабрику періоди «пік», «напівпік» \\
та «ніч». Наведено технологї зменшення \\
енерговитрат управлінням реактивною \\
та активною потужностями синхронних \\
двигунів кульових млинів шляхом адап- \\
тивного керування іх збудниками \\
Ключові слова: електроспоживання, \\
збагачувальні фабрики, кульові млини, \\
синхронні двигуни, збудники, адаптачія, \\
інтелектуалізачія
\end{tabular}

Усовериенствовано согласованное управление электропотреблением дробильно-обогатительного комплекса предприятия. Разработан алгоритм управления предприятием в периоды ограничениймощности әнергосистемы. Уменьшение удельных әнергозатрат достигнуто управлением электропотреблением дробильной $и$ обогатительной фабрик в периодъ «пик», «полупик» и «ночь». Приведены технологии уменьшения энергозатрат управлением реактивной и активной мощностями синхронных двигателей шаровых мельнии, путем адаптивного управления их возбудителями

Ключевые слова: әлектропотребление, обогатительные фабрики, шаровые мельницы, синхронные двигатели, возбудители, адаптация, интеллектуализация
UDC 681.5:621.313.323

DOI: $10.15587 / 1729-4061.2017 .91768$

\section{IMPROVING COORDINATED MANAGEMENT OF ELECTRIC CONSUMPTION BY A CRUSHING- ENRICHMENT COMPLEX OF AN ENTERPRISE}

\author{
V. Khorols k y i \\ Doctor of Technical Sciences, Professor* \\ E-mail: Khorolv@ukr.net \\ D. K I y u e v \\ $\mathrm{PhD}$, Associate Professor* \\ E-mail: dukpost@ua.fm \\ V. K hot skin a \\ $\mathrm{PhD}$, Assistant Professor
}

Department of Informational Technologies Kryvyi Rih Economic Institute of the Kyiv National Economic

University named after Vadym Hetman Poshtoviy ave., 64, Kryvyi Rih, Ukraine, 50000 E-mail: valentina.hockina@mail.ru

D. Khorols k y i Head master Crushing complex

JSC «South Mining and Processing Plant»

Kryvyi Rih, Ukraine, 50026

*Department of general engineering disciplines and equipment Donetsk National University of Economics and Trade named after Michael Tugan-Baranowski Tramvayna str., 16, Kryvyi Rih, Ukraine, 50005

\section{Introduction}

The main task of enterprises of mining-metallurgical complex of Ukraine over strategic period to 2030 is to increase competitiveness of iron ore products (IOP) up to the requirements of the world market for concentrates and pellets. For this purpose, it is necessary to reduce specific energy consumption by $25-35 \%$ from the level of 2013 [1].

There is a high level of energy consumption to produce one tone of IOP at the enterprises of mining-metallurgical complex (MMC). This requires from energy managers to perform the calculation and optimization of electricity consumption, as well as of gas, water, steam, diesel fuel, oil, balls and other materials [2]. In order to reduce the cost of production and increase its quality to the level of European standards, the
MMC enterprises devised methods for managing the production of concentrate and pellets under conditions of multi-zonal tariff for electricity [2]. Thus reducing energy costs of these production processes is a relevant task for energy management up to 2020. This can be achieved by the introduction at MMC enterprises of automated control systems for power consumption by crushing and ore enrichment plants (OEP). The operation of such systems should be aligned with the optimization of technological processes in the production of concentrate for pelletizing plants or agglomeration [3].

Thus, the task of further improving the principles of intelligent management of the processes of electricity consumption by crusher-enrichment complex under conditions of limitations in the system power capacity is a relevant and timely one. 


\section{Literature review and problem statement}

A problem of efficiency of energy supply systems at enterprises of different industries is closely associated with energy development strategy of Ukraine to 2030 [4]. Scientists have developed and demonstrated over recent years:

- a method of short-term neuro-fuzzy electricity consumption forecast [5];

- examples of power consumption control based on neuro-models [6];

- a strategy of energy saving in the technologies for iron ores processing [7].

They devised principles for scientifically substantiated energy saving management of crusher-enrichment complexes at the MMC enterprises based on the optimization of technological modes of power-consuming equipment [8]. A modeling of specific electricity consumption in the ore crushing process was examined [9]; an adaptive control was executed over the energy efficiency processes in ore pretreatment [10]. The systems for automated accounting and managing the power consumption at enterprises based on modern SCADA systems were designed in a number of papers [11]. An increase in the efficiency of electric saving processes was achieved by the methods of artificial equalization of the load schedules [12]. There are known methods for controlling the excitation of synchronous motors to reduce the fee for overflows of reactive power and payment for them [13].

A practice of the SCADA systems implementation for energy saving at the MMC enterprises based on the $\mathrm{Ci}$ tectSCADA package [www.scada.ru] showed their high performance efficiency in the energy consumption management system [1].

But effective electricity consumption depends on many unresolved issues. They include: automation of power supply, designers' capability to develop intelligent control systems that are invariant to perturbations in the technological processes over periods of limited supply from energy system and rolling blackouts. In addition, development of multi-level power consumption control systems for crushing and enrichment complexes with the introduction of intelligent systems for managing reactive and active capacities of an enterprise during "peak", "half-peak" and "night" periods has not been explored in detail.

\section{The aim and tasks of the study}

The aim of present work is to solve the task of automated control over the trajectory of energy consumption by crushing and enrichment complex of an enterprise in the periods of limited power supply. Due to the development of a system for intelligent management and prediction of active and reactive capacities at constant control over geometry of inner-mill loading, it will make it possible to reduce the effect of perturbations in the input characteristics of iron ore on the parameters of power consumption.

To achieve the set aim, the following tasks were to be solved:

- to explore the electricity consumption process by the enterprise with crushing and enrichment complex and to build a model of causation for the optimal trajectory of energy consumption;
- to construct an integrated intelligent control system of power consumption by an enterprise with neural network predicting systems;

- to synthesize a control over trajectory of energy consumption by crushing and enrichment complex depending on the benefit criterion in the generation of reactive capacity.

\section{Materials and methods for examining energy consumption by enterprises of mining-metallurgical complex}

Corporate enterprises in Ukraine: JSC "SevGOK", RJSC "ArcelorMittal Kryvyi Rih, JSC "InGOK”," PJSC "YuGOK", JSC «CGOK» with a load from 200 to 1000 MW belong to large consumers of electricity. Most of the technological production of electricity supply at these enterprises is related to category I and II of electricity receivers according to «Rules for Electrical Installation» [13].

In general, electrical services (ES) of crushing and enrichment complex at an enterprise and trajectory of power consumption can be described by a system of dependences in the form:

$$
\mathrm{ES}=\left\{\mathrm{P}_{\max } \cdot \mathrm{K}_{\mathrm{dc}} \cdot \mathrm{T} \cdot \mathrm{D} \cdot \mathrm{P}_{\mathrm{m}} \cdot \mathrm{A}_{\mathrm{l}} \cdot \mathrm{A}_{\mathrm{ep}}\right\}
$$

where $\mathrm{P}_{\max }$ is the maximum half hour load of enrichment plant; $\mathrm{K}_{\mathrm{dc}}$ is the demand coefficient; $\mathrm{T}$ is the annual number of hours of using maximum load $\mathrm{T}_{\max }(\mathrm{h})$; $\mathrm{D}$ is the number of installed electric motors (units); $\mathrm{P}_{\mathrm{m}}$ is the mean motor power, $\mathrm{kW} ; \mathrm{A}_{\mathrm{l}}$ is the labor electricity intensity ( $\mathrm{Mw} \mathrm{h} /$ person); $\mathrm{A}_{\mathrm{ep}}$ is the labor productivity of electrical-technical personnel ( $\mathrm{Mw} \mathrm{h} /$ person).

An optimization of the power supply processes at a crushing and enrichment complex is performed through the management of trajectory in power consumption by the complex based on the causal model [14]. Fig. 1 shows a causal model for the enterprise's power consumption control, which is characterized by detailed impacts of groups of factors on the trajectory of energy consumption by the complex (personnel, electrical services, power consumption management, perturbations, electricity network and the intelligentization).

The need for energy saving at the MMC enterprises in Ukraine at all stages of manufacturing iron ore products (IOP) is also predetermined by the increase in prices for electricity in 2016. At the same time, the growth of its contribution to the cost of products in the energy-intensive technologies of extraction of crude ore, crushing, grinding, enrichment, pelletizing, baking is up to 60 per cents $[1,2,9]$.

A special feature of modern control over power consumption by the MMC enterprises is the introduction of energy management systems and automated systems for electricity accounting and control (ASEAC). All Kryvy Rih-based MMC enterprises pay to PAT "DTEK DNIPROOBLENERGO" (Ukraine) for consumed electricity according to a three-zonal tariff [1,3], that is, a 1.5 tariff during time of maximum load in the power system (from $8 \mathrm{a} . \mathrm{m}$. to $11 \mathrm{a} . \mathrm{m}$. and from $8 \mathrm{p} . \mathrm{m}$. to 10 p. m.); full tariff in the half-peak period (from 7 a.m. to 8 a. m., from 11 a. m. to 8 p.m., from 10 p.m. to 11 p.m.); a 0.4 tariff in the night hours of minimum load in the energy system (from 11 p. m. to 7 a. m.). The transition to this tariff stimulates energy management at the enterprises of crushing and enrichment complex of the enterprise to separate some of the workshops (plants) as energy consumers - regulators, differentiated by category and period of their work during 24 hours. 


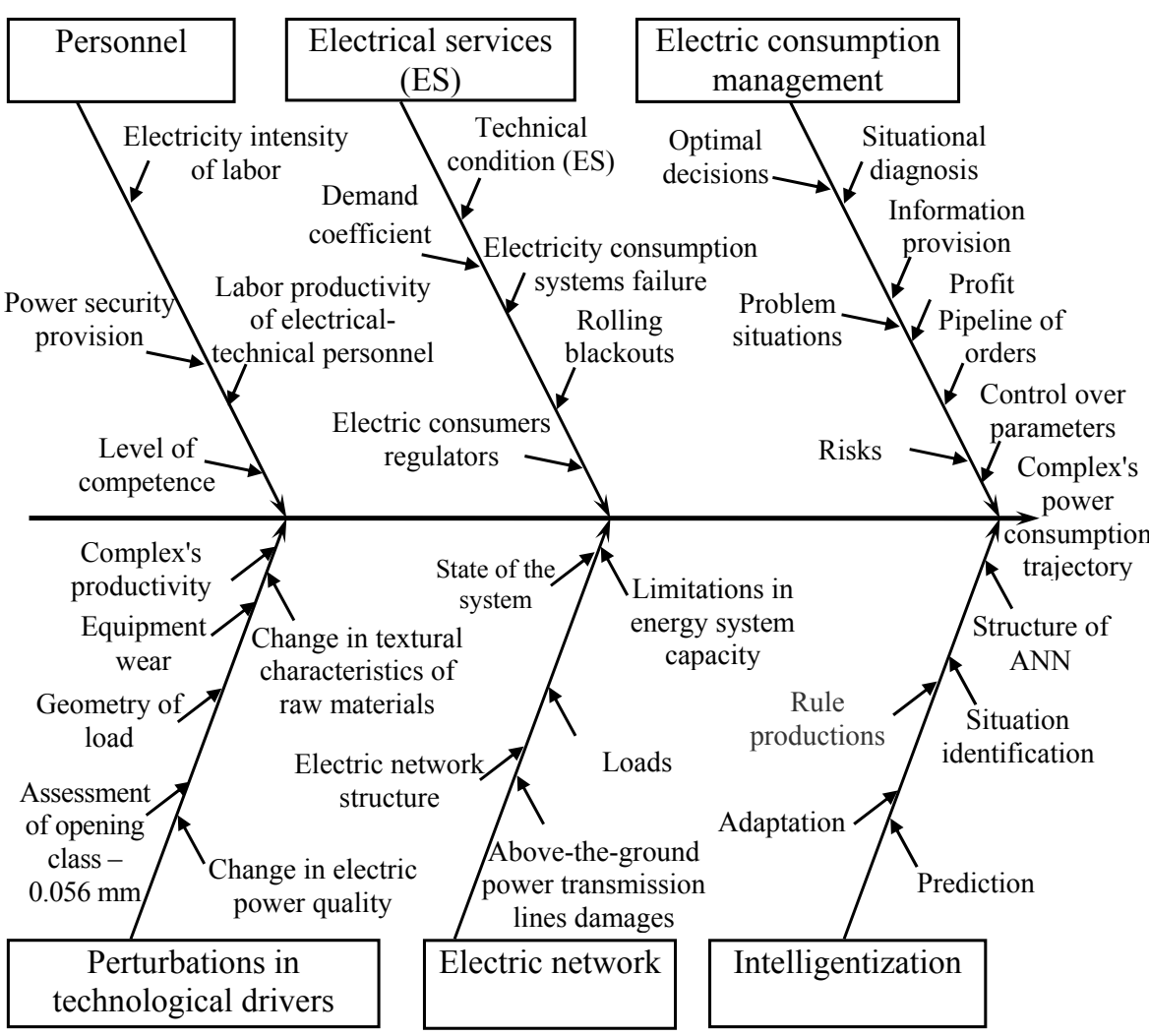

Fig. 1. Causal model of power consumption management in crushing and enrichment complex at an enterprise uniform information platform of SCADA-systems, ASEAC, automated power consumption control systems (APCS). In turn, the trajectory of energy consumption by enterprises under conditions of power capacity limitations defines the trajectory of optimal production using the automated control systems for technological processes (ACS TP) [15].

Hence it follows that the integrated automated management system of an enterprise may be represented in the form of three interconnected levels of control.

The lower level is formed of:

- ACS TP of mining, transporting raw ore, crushing plant, enrichment plant, pelletizing factories, baking;

- APCS for technological operations and workshops interconnected by SCADA-systems and automated control systems of SM, CER exciters and sources of reactive power (SRP).

The medium level is formed of MES (Manufacturing Execution System) of the system [16], which are focused on:

In the periods of maximum load, crushing plants may turn into consumers - electricity regulators (CER). Synchronous motors for sludge pumps become not only electricity regulators but the reactive capacity compensators as well. This makes it possible to reduce the cost of electricity by $5-10 \%$ from the limited ones [3, 12].

Another feature of the MMC enterprises is that they use as electric drives for the most energy-intensive technological processes the synchronous motors (SM) with capacity from $2500 \mathrm{~kW}$ up to $5000 \mathrm{~kW}$, the asynchronous motors with capacity from $5 \mathrm{~kW}$ to $600 \mathrm{~kW}$ and DC motors - thyristor converters, condenser batteries, etc. For the purpose of analysis and optimization of energy consumption at the MMC enterprises, a structure of electrical network can be represented in the form of set $\mathrm{J}=[\mathrm{j}], \mathrm{j}=1,2 \ldots \mathrm{n}$ - levels of hierarchy. These levels include:

- input feeders at the enterprise;

- transformer substations;

- power transformers;

- groups of electricity consumers that are involved in the technological process;

- the largest energy-intensive consumers (ball mills, self-grinding mills with a standard synchronous electric drive (SM) with capacity $\mathrm{P}_{\mathrm{QM}}=2500-5000 \mathrm{~kW}$ and higher.

\section{Results of examining coordinated intelligent management of power consumption at a crushing and enrichment complex}

The proposed technique for analysis of electricity services allows us to automate the process of managing the trajectory of energy consumption by a MMC enterprise based on the
- informatization of tasks in operational planning and control over production of concentrate and pellets;

- optimization of production processes;

- assessment of consumption of electricity, gas, water, oil, diesel fuel;

- control and scheduling of the fulfillment of plans and pipeline of orders from metallurgical plants;

- scheduling of power supply.

The top level in the computer aided management (CAM system) of an enterprise is formed by the ERP-systems. They provide for the solution of strategic tasks when fulfilling the pipeline of orders for production, resource management, investment and provide support for business processes of the enterprise as a whole [1].

Fig. 2 shows the structure of an integrated intelligent system. This system ensures the optimization of fulfilling the pipeline of orders from metallurgical plants during periods of limited power supply. It is performed by using expert systems (ES) through compiling a database (DB), knowledge base (KB), dynamic base of operational technological data (DBOTD), dynamic base of operational condition of the power system (DBOCP) and rules base (RB). A special feature of the developed system is the integration of ES into CAM - MES - ERP systems. This approach provides for: coordinated work of the management and information subsystems of ACS of an enterprise, diagnosis of problem situations and assessment of technological-energy situations, decision making on parameters $\mathrm{P}_{\mathrm{i}}, \mathrm{Q}_{\mathrm{i}}$, and search for optimal solutions when determining BOT and SRP.

The lower level (CAM, APCS) is the most intensive by the volume of information. It is also limited in time regarding the reaction to a disturbance, both in the energy system and in the technological system of production. CAM, APCS, 
SCADA-systems accumulate and process a large number of technological, energy parameters and create informative base of source data for MES-systems.

In turn, the information accumulated by SCADA-systems compiles a database (DB) to predict both technological parameters of the production and parameters $\mathrm{P}_{\mathrm{i}}, \mathrm{Q}_{\mathrm{i}}$. To forecast $\mathrm{P}_{\mathrm{i}}, \mathrm{Q}_{\mathrm{i}}$ synced with the process, we used in present work artificial neural network models (ANN) [17].

Trained ANN for predicting reactive power of an enterprise $Q_{E p}$ are shown in Fig. 3, $a$; trained ANN of active power $\mathrm{P}_{\mathrm{Ep}}$ are shown in Fig. 3, $b$. ANN consists of three layers of the network, which includes $\mathrm{Q}_{\mathrm{i}}, \ldots \mathrm{Q}_{\mathrm{k}}$ - signals (Fig. 3,a). At the output of the system we obtain $Q_{\mathrm{Ep}}\left(\mathrm{t}+\tau^{*}\right)$ - source signals of the network with weight coefficients $\mathrm{w}_{\mathrm{ij}}{ }^{1}, \mathrm{w}_{\mathrm{ij}}{ }^{2}$.
50-250 learning iterations. By the combined algorithm, it is $12-16 \mathrm{~s}$ at 1000 network learning iterations. After conducting the prediction, the model recommends guidelines on selecting the number of SRP at the inputs of electric energy and manages the exciters of ball mills SM, sludge pumps SM, pelletizing and baking plant's exhausters SM.

Let us consider in more detail controlling the trajectory of power consumption by OEP depending on the technological modes in the operation of crushing and enrichment complex.

Fig. 4 shows a diagram of an automated control system over power consumption at the first, second and third stages of OEP enrichment at an enterprise. A system of power consumption of each of 20 technological sections of the ore enrichment plant is adapted to non-stationary technological modes in the operation of equipment and is characterized by invariance to the types of ore that are supplied for enrichment [15]. The trajectories of energy consumption at ore enrichment plants in moment $\mathrm{T}_{\mathrm{i}}$ match the natural trajectory of producing the concentrate with mass fraction of iron at $\beta_{\text {Feconc }}=\{65,8 \div$ $\div 66,5 \%$ and technological parameters that define the geometry of the inner-mill load of ball mills at the first, second, third stages, respectively, $\varphi_{1}, \varphi_{2}, \varphi_{3}, \varphi_{4}$.

Ball mills discharges BM1, BM2, BM3, BM4 are characterized also by technological parameters that define energy efficiency of IOP. They include: $\mathrm{Q}_{1 \mathrm{c}}{ }^{(\mathrm{BM} 1)}, \mathrm{Q}_{1 \mathrm{c}}{ }^{(\mathrm{BM} 2)}, \mathrm{Q}_{2 \mathrm{c}}{ }^{(\mathrm{BM} 3)}$, $\mathrm{Q}_{3 c^{(B M 4)}}$ is the productivity performance of ball mills $(\mathrm{t} / \mathrm{h})$ at the first, second and third stage of enrichment; consumption of water fed to the mills at the first stage of enrichment $W_{B}{ }^{(K M 1)}$, $\mathrm{W}_{\mathrm{B}}{ }^{(\mathrm{KM} 2)}$. Other technological parameters are controlled by sensors $\mathrm{S}_{1}, \mathrm{~S}_{2} \ldots \mathrm{S}_{20}$.

The work of an ore enrichment plant is estimated by expert system by the source indicators: $\mathrm{Q}^{\mathrm{F}}{ }_{-0,056}$ is the plant productivity by the class of $-0.056 \mathrm{~mm} ; \mathrm{Q}^{\mathrm{F}}$ conc is the plant productivity in the production of concentrate with a content of mass fraction of iron $\beta_{\text {Feconc }}$ and parameters of iron in tails $\left(\alpha_{\mathrm{m}}\right)$.

In this case, the cost of active power depends on the zone (time of day) and is defined by the tariff "peak - half-peak - night". The cost of reactive power depends on the nature of electric drives load at a crushing and enrichment complex and on the means of compensation for the reactive load that it is equipped with.

In this case, an important issue of coordinated management over the trajectory of energy consumption is:

- to devise a method to control the excitation of syn-

Configuration of the network for predicting reactive load represents a structure in whose input layer are 4 neurons, 3 in the medium and 1 neuron in the output layer: ANN with the structure 4-3-1. Training the network was conducted using a combined method, the sequence of learning is 50 samples, training period is $10 \mathrm{~s}$ at a number of iterations (steps) 300-500.

A period of training ANN (Fig. 3, $b$ ) for the prediction of active loads $\mathrm{P}_{\mathrm{Ep}}$ of the enterprise when training the network by the algorithm of error back propagation is $5 \mathrm{~s}$ at chronous motors of ball mills electric drive BM1, BM2, $\mathrm{BM} 3, \mathrm{BM} 4$ to reduce the fee for reactive power overflows [13];

- to design an algorithm for energy efficiency of the reactive energy compensation by using synchronous motors of ball mills at the first, second and third stages of enrichment;

- to develop methods to correct adaptive regulators of ball mills' synchronous motors exciters. 


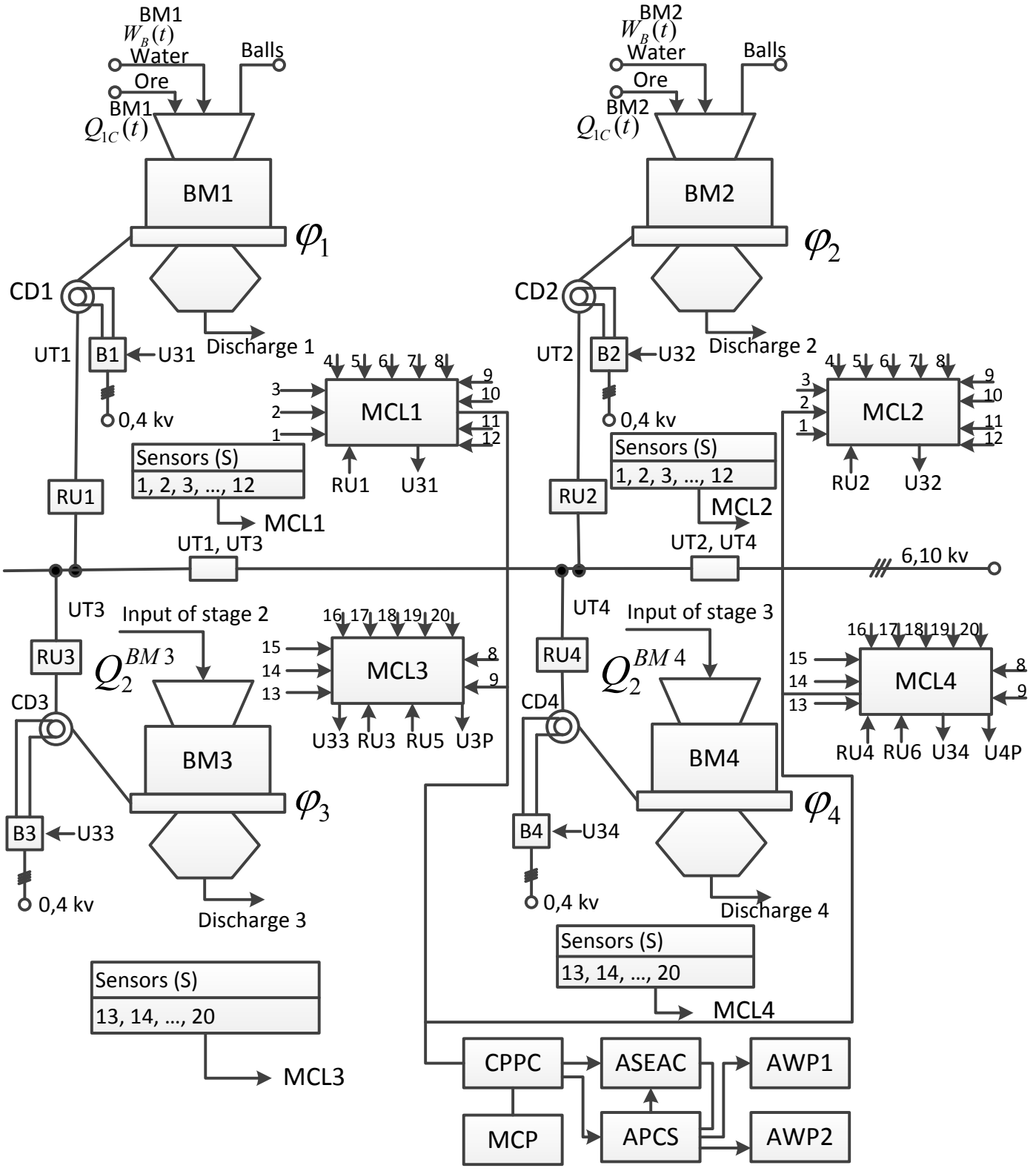

Fig. 4. Automated power consumption control system of ore enrichment plant

\section{Discussion of results of intelligent control over power consumption in the complex}

An influence of fluctuations in quality properties of ore characteristics on the active power of electric drives of classifiers and magnetic separators was examined [8]. This approach allows indirect assessment of electricity consumption in the production with planned technological parameters: $\mathrm{Q}_{-0,056}^{\mathrm{F}}, \mathrm{Q}_{\text {conc }}^{\mathrm{F}}, \beta_{\mathrm{Feconc}}, \alpha_{\mathrm{m}}$. With a change in the texture characteristics of raw ore, parameters of specific electricity consumption for opening the grain of iron to class $0,056 \mathrm{~mm}$ change, too [15]. Then the estimated electricity consumption will be assessed by formula:

$$
\mathrm{W}_{\mathrm{K}}=\mathrm{Q}_{\max }^{\mathrm{F}} \cdot \mathrm{K}_{\mathrm{sr}} \cdot\left(\beta_{-0,056}^{\mathrm{K}}-\beta_{-0,056}^{\text {s.r. }}\right) \cdot \mathrm{e}_{\mathrm{pit}}^{\mathrm{F}},
$$

where $\mathrm{K}_{\text {s.r. }}$ is the coefficient that reflects the dependence of percentage content of hard-to-enrich varieties of raw ore (s.r.) that is supplied for enrichment; $\left(\beta_{-0.056}^{\mathrm{K}}-\beta_{-0.056}^{\text {s.r. }}\right)=$ $=\Delta_{-0,056} \beta_{-0,056}^{\mathrm{K}}-\beta^{\text {s.r. }}$ is the increment of prepared class $0.056 \mathrm{~mm}$ in the concentrate in the processes of crushing, classification and enrichment; $\mathrm{e}_{\mathrm{pit}}^{\mathrm{F}}$ is the specific electricity consumption to produce one tone of concentrate with assigned parameters $\beta_{\text {Feconc }}, \alpha_{\mathrm{m}}$ and humidity $\mathrm{B}_{\text {ass }}<10 \%$.

If the power system established a limit for electricity to a company during periods of limited capacity, then

$$
\max \left[\sum_{\mathrm{i}=1}^{\mathrm{n}} \int_{0}^{\mathrm{t}+30} \mathrm{P}(\mathrm{t}) \mathrm{dt}\right] \leq \sum_{\mathrm{i}=1}^{\mathrm{n}} \mathrm{P}_{\mathrm{LIM}}=\mathrm{K}_{\mathrm{DC}} \cdot \mathrm{P}_{\mathrm{NOM}},
$$

where $\mathrm{P}(\mathrm{t})$ is the active maximum plant capacity in the period of limited power in electrical system; $\mathrm{P}_{\text {LIM }}$ is the estimated limited power; $\mathrm{P}_{\mathrm{NOM}}$ is the nominal power; $\mathrm{n}$ is the number of OEP technological sections; $\mathrm{t}_{0}<\mathrm{t} \leq \mathrm{t}_{\mathrm{t}-30}$.

Calculated reactive and full powers are equal to:

$$
\mathrm{Q}_{\mathrm{p}}=\mathrm{P}_{\mathrm{LIM}} \cdot \tan \varphi, \mathrm{S}_{\mathrm{p}}=\sqrt{\mathrm{P}_{\mathrm{LIM}}^{2}+\mathrm{Q}_{\mathrm{p}}^{2}}
$$

The values $\mathrm{W}_{\mathrm{k}}, \mathrm{P}(\mathrm{t}), \mathrm{P}_{\mathrm{LIM}}, \mathrm{Q}_{\mathrm{p}}, \mathrm{S}_{\mathrm{p}}$ over each of prediction periods $t_{1}, t_{2}, t_{3}$ will be matched by expert values $Q_{\text {conc }}^{F}$, 
$\mathrm{Q}_{-0.056}^{\mathrm{F}}$ and current values of parameters $\varphi_{1}, \varphi_{2}, \varphi_{3}, \varphi_{4}, \mathrm{Q}_{1 \mathrm{c}}^{\mathrm{BM} 1}$, $\mathrm{Q}_{1 \mathrm{c}}^{\mathrm{BM} 2}, \mathrm{Q}_{2 \mathrm{c}}^{\mathrm{BM} 3}, \mathrm{Q}_{3 \mathrm{c}}^{\mathrm{BM} 4}, \mathrm{~W}_{\text {input }}^{\mathrm{BM} 1}, \mathrm{~W}_{\text {input }}^{\mathrm{BM} 2}$.

The above enumerated parameters will be assumed as approximated sets, to assess which, similar to described earlier, we shall use artificial neural networks (ANN) [17], by the readings from sensors $\mathrm{S}_{1}, \mathrm{~S}_{2}, \ldots \mathrm{S}_{20}$. In the automated power consumption control system (APCS), neural networks will be used also in the tasks on processing the information, on the identification of nonlinear systems, forecasting, in filtering the adapted control, pattern recognition and diagnosis.

In APCS, an automated control over parameters of electricity consumption is performed for each of 20 technological sections. With the help of ASEAC, we constructed a predictive neural network model and managing neural network model: $\mathrm{P}_{\mathrm{i}}$ - active power; $\mathrm{Q}_{\mathrm{i}}$ - reactive power; $\mathrm{U}_{\mathrm{i}}$ - voltage.

Therefore, APCS carries out monitoring of the trajectory of OEP energy consumption $\mathrm{T}_{\mathrm{E}}^{\mathrm{F}}$ by each of twenty technological sections:

$$
\overline{\mathrm{T}}_{\mathrm{E}}^{\mathrm{F}}=\left\{\overline{\mathrm{T}}_{\mathrm{E}_{1}}^{1}, \overline{\mathrm{T}}_{\mathrm{E}_{2}}^{2}, \overline{\mathrm{T}}_{\mathrm{E}_{3}}^{3}, \ldots, \overline{\mathrm{T}}_{\mathrm{E}_{20}}^{20}\right\},
$$

to which the trajectory will match

$$
\overline{\mathrm{T}}_{\beta \mathrm{Fe}}^{\mathrm{F}}=\left\{\overline{\mathrm{T}}_{\beta \mathrm{FeK} 1}^{1}, \overline{\mathrm{T}}_{\beta \mathrm{FeK} 2}^{2}, \overline{\mathrm{T}}_{\beta \mathrm{FeK} 3}^{3}, \ldots, \overline{\mathrm{T}}_{\beta \mathrm{FeK} 20}^{20}\right\}
$$

of the production of IOP with assigned quality. In the case of breakdowns in the power supply system or reduction in limit $\mathrm{P}_{\text {LIM }}$, rolling blackouts

$$
\overline{\mathrm{T}}_{\Delta \mathrm{QCONC}}^{\mathrm{F}}=\left\{\overline{\mathrm{T}}_{\Delta \mathrm{QCONC} 1}^{1}, \overline{\mathrm{T}}_{\Delta \mathrm{QCONC} 2}^{2}, \overline{\mathrm{T}}_{\Delta \mathrm{QCONC} 3}^{3}, \ldots, \overline{\mathrm{T}}_{\Delta \mathrm{Q} \mathrm{CONC} 20}^{20}\right\}
$$

the trajectories of IOP production will correspond to the situation of failure to fulfill the pipeline of orders from metallurgical plants of Ukraine and the EU countries.

The above listed technological trajectories will be accompanied by technological, financial, economic risks [1, 15], which are caused by changes in texture characteristics of ore supplied for enrichment, by the condition of technological equipment and electrical equipment and, accordingly, OEP power supply. Thus, normal situation $\left\{\overline{\mathrm{S}}_{\mathrm{E}}^{\mathrm{H}}\right\}$ will be matched by its own trajectory of energy consumption $\left\{\overline{\mathrm{T}}_{\mathrm{E}}^{\Phi}\right\}$, trajectory of production of the concentrate with required quality $\left\{\overline{\mathrm{T}}_{\beta \mathrm{Fe}}^{\mathrm{F}}\right\}$, trajectory of minimizing the loss of products $\left\{\overline{\mathrm{T}}_{\triangle \mathrm{QCONC}}^{\mathrm{F}}\right\}$ and minimum risks of failure to meet the planned indicators in terms of reducing profit $\overline{\mathrm{P}}_{\mathrm{F}}^{\mathrm{N}} \rightarrow \overline{\mathrm{P}}_{\mathrm{F}}^{\mathrm{N}}$ zad.zn.

In case of problems, anomalies, emergency and post emergency situations in the power system, APCS acts in the following way. It gives recommendations to the operational personnel (AWP of OEP shift manager, AWP of OEP energy dispatcher). Based on the information, a decision is made regarding attainment of power consumption at trajectory $\left\{\overline{\mathrm{T}}_{\mathrm{E}}^{\Phi}\right\}$. By the sensors information of both electrical and technological variables, parameters are optimized: $\mathrm{P}_{1}(\mathrm{t})$, $\mathrm{P}_{2}(\mathrm{t}), \ldots \mathrm{Q}_{1 \mathrm{P}}(\mathrm{t}), \mathrm{Q}_{2 \mathrm{P}}(\mathrm{t}), \mathrm{Q}_{3 \mathrm{P}}(\mathrm{t}), \ldots \mathrm{Q}_{1 \text { INPUT }}(\mathrm{t}), \mathrm{Q}_{2 \text { INPUT }}(\mathrm{t}), \ldots$

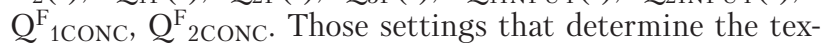
tural characteristics of raw ore, the geometry of inner-mill load of ball mills $\varphi_{1}, \varphi_{2}, \varphi_{3}, \varphi_{4}$, opening of magnetite to the class $-0.056 \mathrm{~mm}$, will be assessed using artificial five-layered neural network. It learns through the back propagation procedure [17].

For the prediction of OEP reactive load $\mathrm{Q}_{\mathrm{P}}(\mathrm{t})$, we used in present work a three-layered ANN. The input layer contains 4 neurons, 3 in the middle and 1 neuron in the output layer, that is, the 4-3-1 structure. For the prediction of active loads $\mathrm{P}_{1}(\mathrm{t}), \mathrm{P}_{2}(\mathrm{t}), \ldots$, we used in present work the 5-3-1 architecture of ANN neural network by applying the algorithm of back propagation [17].

The exclusion of technological overrun of active power by enterprise $\mathrm{P}_{\text {nom }}(\mathrm{t})$ in period $\mathrm{T}_{\text {limitation }}$ is achieved by controlling the value of this power by the ASEAC system in fixed time intervals $t_{1}, t_{2}, t_{3}, \ldots$

To ensure cost-effective modes of the enrichment production operation, power system sets a limit on the level of reactive power of electricity consumers: the maximum and minimum value of reactive power. These limitations are usually differentiated over periods of day (they are functions of current time). Voltage at the SM electro terminals BM UT1, UT2, UT3, UT4, in this case, should not exceed permissible limits: maximum and minimum values set by normative documents (voltage fluctuation in electro terminals is permissible within $\pm 5 \%$ or from $-5 \%$ to $+10 \%$ of the nominal voltage) [13].

Maintaining the voltage within the assigned norms makes it possible to minimize the losses of active power in induction motors (IM) of qualifiers, separators and hydrocyclones pumping units, that is, to reduce their additional consumption of reactive power. This value is considerable, since at increasing voltage by $1 \%$, reactive power consumed by IM increases by $3 \%$ [13].

This approach allows us to increase efficiency in managing stages related to obtaining the class $-0,056 \mathrm{~mm}$ by selecting rational parameters $\varphi_{3}, \varphi_{4}$, and accordingly, to use SD of ball mills at the first, second and third stages to generate reactive power $\mathrm{Q}_{2 \mathrm{P}}(\mathrm{t}), \mathrm{Q}_{3 \mathrm{P}}(\mathrm{t})$. These functions are performed in APCS by microcontrollers MCL 1, 2, 3, 4, information from which is sent to the central neuro-processor of power consumption control (CPPC) and, accordingly, to the ASEAC and APCS systems, AWP.

We developed a two-step control system of power consumption. In the system, information from sensors $\mathrm{S}_{1}-\mathrm{S}_{12}$ characterizes the work of the first stage of enrichment and loading of ball mills BM1, BM2. Information from sensors $\mathrm{S}^{2}{ }_{13}-\mathrm{S}^{2}{ }_{20}$ characterizes the work of the second stage of enrichment with a ball mill BM3. Information from sensors $\mathrm{S}^{3}{ }_{13}-\mathrm{S}^{3}{ }_{20}$ characterizes the work of the third stage of enrichment with ball mill BM4. Electric devices of technological units, controlling elements form a lower level of management over technological process and power consumption by OEP technological sections (level of management by controllers).

The top management level over OEP power consumption and the production of concentrate, along with ASEAC and APCS, forms a dispatcher point and represents AWP1 shift manager and AWP2 - energy dispatcher.

The base of dispatcher point is the monitor of corporate performance (MCP), which displays not only the elements of OEP power consumption system, technological process of enrichment, but also their relationships and communication dynamics. All this creates a conditional picture (a schematic) of the OEP energy and technological process. In addition, OEP APCS through information channels of MES and ERP form an intelligent control system of power 
consumption (Fig. 2). In such systems, a disturbance from the impact of texture characteristics of raw ore on the electricity consumption parameters will be assessed by using Petri networks [15].

CPPC neuro-procesor carries out the recognition of parameters $\varphi_{1}, \varphi_{2}, \varphi_{3}, \varphi_{4}$, evaluates $\overline{\mathrm{U}}_{\mathrm{T} 1}, \overline{\mathrm{U}}_{\mathrm{T} 2}, \overline{\mathrm{U}}_{\mathrm{T} 3}, \overline{\mathrm{U}}_{\mathrm{T} 4}$ and determines the extremum of function EC (economic criteria) of benefit from generating reactive power by synchronous motors of electric drives of plant's ball mills.

$$
\mathrm{EC}=\mathrm{EP}_{\mathrm{Q}}-\mathrm{EPR}_{\mathrm{m}}=\mathrm{C}_{\mathrm{Q}}-\mathrm{C}_{\mathrm{P}_{\mathrm{m}}}=\mathrm{f}\left(\alpha_{\mathrm{OPT}}\right),
$$

where $\mathrm{EP}_{\mathrm{Q}}$ is the economic indicator of production (consumption) of reactive power; $\mathrm{EPR}_{\mathrm{m}}$ is the economic indicator of active power consumption; $\mathrm{C}_{\mathrm{Q}}$ is the magnitude (price) of payment for the power generated overt time $t ; \mathrm{C}_{\mathrm{Pm}}$ is the magnitude of payment for the active power used for it.

EC factor is functionally dependent on $\alpha_{\mathrm{OPT}}-$ optimal load angle of synchronous motor of ball mill by reactive power. It corresponds to the optimal mode of payment for the consumed active power that is used to generate reactive power in the terminals of synchronous motors BM1, BM2, BM3, BM4.

Thus, the condition for entering such a mode is the CPPC prediction by technological parameters of the state of power consumption at each stage $\mathrm{P}_{1}, \mathrm{P}_{2}, \mathrm{P}_{3}, \mathrm{P}_{4}, \mathrm{Q}_{\mathrm{P} 1}, \mathrm{Q}_{\mathrm{P} 2}$, $\mathrm{Q}_{\mathrm{P} 3}, \mathrm{Q}_{\mathrm{P} 4}$ at

$$
\overline{\mathrm{U}}_{\mathrm{T} 1}, \overline{\mathrm{U}}_{\mathrm{T} 2}, \ldots, \overline{\mathrm{U}}_{\mathrm{T} 4}=\mathrm{const}
$$

and $\mathrm{e}^{\mathrm{F}}{ }_{\mathrm{PYT}} \rightarrow \mathrm{e}^{\mathrm{F}}$ PYT zad. Using trained CPPC NN by parameters:

$$
\begin{aligned}
& \left\{\varphi_{1}, Q_{1 \mathrm{C}}^{\mathrm{BM} 1}(\mathrm{t}), \mathrm{CN} 1\right\} \rightarrow \text { assesses } \alpha_{\mathrm{OPT}} \mathrm{CD} 1 ; \\
& \left\{\varphi_{2}, Q_{1 \mathrm{C}}^{\mathrm{BM} 2}(\mathrm{t}), \mathrm{CN} 2\right\} \rightarrow \text { assesses } \alpha_{\mathrm{OPT}} \mathrm{CD} 2 ; \\
& \left\{\varphi_{3}, Q_{3 \mathrm{C}}^{\mathrm{BM} 3}(\mathrm{t}), \beta_{\mathrm{Fe}}^{2}\right\} \rightarrow \text { assesses } \alpha_{\mathrm{OPT}} \mathrm{CD} 3 ; \\
& \left\{\varphi_{3}, Q_{4 \mathrm{C}}^{\mathrm{BM} 4}(\mathrm{t}), \beta_{\mathrm{Fe}}^{3}\right\} \rightarrow \text { assesses } \alpha_{\mathrm{OPT}} \mathrm{CD} 4 .
\end{aligned}
$$

Optimal setpoints for ball mills' SM exciters are determined as follows:

$$
\begin{aligned}
& \overline{\mathrm{U}} 31[\mathrm{n}+1]=\overline{\mathrm{U}} 31[\mathrm{n}]+\mathrm{K} 1\left(\overline{\mathrm{U}}_{\mathrm{Bmax}}-\overline{\mathrm{U}}_{\mathrm{BO}}\right) \mathrm{e}^{-\frac{\mathrm{t}}{\tau_{\mathrm{B} 1}}}, \\
& \overline{\mathrm{U}} 32[\mathrm{n}+1]=\overline{\mathrm{U}} 32[\mathrm{n}]+\mathrm{K} 2\left(\overline{\mathrm{U}}_{\mathrm{Bmax}}-\overline{\mathrm{U}}_{\mathrm{BO}}\right) \mathrm{e}^{-\frac{\mathrm{t}}{\tau_{\mathrm{B} 2}}}, \\
& \overline{\mathrm{U}} 33[\mathrm{n}+1]=\overline{\mathrm{U}} 33[\mathrm{n}]+\mathrm{K} 3\left(\overline{\mathrm{U}}_{\mathrm{Bmax}}-\overline{\mathrm{U}}_{\mathrm{BO}}\right) \mathrm{e}^{-\frac{\mathrm{t}}{\tau_{\mathrm{B} 3}}}, \\
& \overline{\mathrm{U}} 34[\mathrm{n}+1]=\overline{\mathrm{U}} 34[\mathrm{n}]+\mathrm{K} 4\left(\overline{\mathrm{U}}_{\mathrm{Bmax}}-\overline{\mathrm{U}}_{\mathrm{BO}}\right) \mathrm{e}^{-\frac{\mathrm{t}}{\tau_{\mathrm{B} 4}}},
\end{aligned}
$$

where $\overline{\mathrm{U}}_{\mathrm{Bmax}}$ is the maximum voltage that is supplied to the coil of exciter; $\overline{\mathrm{U}} 31, \overline{\mathrm{U}} 32, \ldots$ is the voltage of exciter under nominal mode; $\tau_{\mathrm{B} 1}, \tau_{\mathrm{B} 2}, \tau_{\mathrm{B} 3}, \tau_{\mathrm{B} 4}$ are the time constants of ball mills' SM exciters; K1, K2, K3, K4 are the coefficients that depend on the degree of filling the ball mills $\varphi_{1}, \varphi_{2}, \varphi_{3}, \varphi_{4}$.

Adaptive control systems for the exciters of synchronous motors of ball mills are designed using algorithms for optimal searchless control [18]. Imitation simulation of the operation of intelligent control system for a crushin- genrichment complex is performed under conditions of JSC $\ll$ CGOK». In the process of modeling situations in power consumption, energy managers evaluated operation modes at crushing and enrichment complex over different periods of 24 hours. In this case, CPPC, by obtaining predictive values $\mathrm{P}_{1}(\mathrm{t}), \mathrm{P}_{2}(\mathrm{t}), \mathrm{P}_{3}(\mathrm{t}), \mathrm{P}_{4}(\mathrm{t})$, estimated trajectory of OEP power consumption over 24 hours during "night", "half-peak" and "peak". In case $\mathrm{P}_{\mathrm{FACT}}$ deviates from $\mathrm{P}_{\mathrm{LIM}}$, CPPC works out the subprogram "losses". For this purpose, the CP memory is supplied with a table of priorities from OEP electricity consumers, differentiated by the category "losses" in terms of concentrate production $\mathrm{Q}_{\text {CONC }}^{\mathrm{F}}$. Consequently, CPU works out the following rule.

If $\mathrm{P}_{\text {FACT }} \gg>\mathrm{P}_{\mathrm{LIM}}$, and $\beta_{\text {Feconc }} \rightarrow \beta_{\text {Fezad }}, \mathrm{Q}_{\mathrm{CONC}}^{\mathrm{F}}$ and $\mathrm{T}_{\triangle \mathrm{Q} C \mathrm{NONC}}^{\mathrm{F}}$ corresponds to the assigned value, then it is necessary to disable SM of ball mills at the first stage of enrichment for period $\mathrm{t}_{\text {LIM }}$.

In this situation, OEP energy power will be simultaneously reduced by $100 \mathrm{MW}$. By the command from APCS ACS, technological units at the second and third stages of enrichment will work out the trajectory of concentrate production, providing for the fulfillment of planned production indicators. For the period of "half-peak" we devised the following rule.

If $\mathrm{P}_{\mathrm{FACT}}>>\mathrm{P}_{\text {LIM-HALF-PEAK }}$, and $\beta_{\mathrm{Fe} \text { CONC-HALF-PEAK }} \rightarrow$ $\rightarrow \beta_{\text {Zad }}, Q_{\text {CONC }}^{\mathrm{F}}$ and $\mathrm{T}_{\triangle \mathrm{O} \text { CONC-HALF-PEAK }}^{\mathrm{F}}$ corresponds to the assigned value, then it is necessary to disable only one SM of ball mill KM1 at each of 20 OEP sections.

In this case, OEP energy power will be simultaneously reduced by $50 \mathrm{MW}$. By the command from APCS - ACS, technological units at the first, second and third stages of enrichment will work out the assigned planned indicators of production for the period of "half-peak".

For the period of "night" we devised the following rule.

If $\mathrm{P}_{\mathrm{FACT}}=\mathrm{P}_{\text {LIM-NIGHT }}$, and $\beta_{\mathrm{Fe} \text { CONC-NIGHT }} \rightarrow \beta_{\mathrm{zad}}, \mathrm{Q}_{\mathrm{CONC}}^{\mathrm{F}}$ and $\mathrm{T}^{\mathrm{F}} \mathrm{QCONC}$-NIGHT corresponds to the assigned value, then it is necessary to maximize the production of concentrate by continuous monitoring the factors $\varphi_{1}, \varphi_{2}, \varphi_{3}, \varphi_{4}$ and $\alpha_{\mathrm{m}}$.

In this case, ASEAC - APCS work out the assigned values of trajectory in OEP energy consumption $\mathrm{T}_{\mathrm{E}}^{\mathrm{F}}$. The maximization of factors $Q_{\mathrm{CONC}}^{\mathrm{F}}$ and minimization of $\alpha_{\mathrm{m} \text { min }}$ and, respectively, $\mathrm{e}_{\mathrm{PYT}}^{\mathrm{F}} \rightarrow \mathrm{e}_{\mathrm{PYT} m i n}^{\mathrm{F}}$ were obtained by the optimization of parameters $\alpha_{\mathrm{OPT}} \mathrm{CD} 1, \alpha_{\mathrm{OPT}} \mathrm{CD} 2, \alpha_{\mathrm{OPT}} \mathrm{CD} 3$, $\alpha_{\mathrm{OPT}} \mathrm{CD} 4$. In this case, the minimum electricity consumption $\mathrm{Wk}$ is attained.

A task for APCS ES is to organize timely and full use of the equipment, current information to determine the status of power consumption by the enterprise and to provide staff (DM) with necessary information to making a decision to restore stable OEP operation. Thus, an improvement in effectiveness of managing the modes of power consumption by the MMC enterprises was achieved through coordinated automated control over technological processes in the extraction of ore, grinding, crushing, enrichment, pelletizing and baking, and APCS of power consumption processes, by constructing ES and man-machine decision-making systems.

The systems designed make it possible to meet the requirements of energy generating companies for active and reactive loads, to reduce consumption in the power networks and to maintain voltage in the nodes of electricity receivers within the set norms.

Thus, we improved an intelligent system for coordinated management of power consumption by a crushing and en- 
richment complex of an enterprise over periods of limitations by energy system of power for active and reactive loading. It allows us to reduce losses in the production (of concentrate) during periods of "peak", "half-peak" and to maximize complex's efficiency over the period of "night" by fulfilling "just in time" order from the enterprise's pelletizing plant, as well as fulfill a pipeline of orders from metallurgical plants of Ukraine and the EU countries.

\section{Conclusions}

1. We examined the process of power consumption by the enterprise with crushing and enrichment complex. The causal model is devised. It is proved that the trajectory of energy consumption by crushing-enrichment complex is determined by a group of factors: energy efficiency, productivity, quality of iron ore products and profitability. We present a concept for managing the iron ore production under conditions of limited power from the energy system over the periods "night", "peak", and "half-peak". It is distinguished by taking into account the possibility to function under conditions of rolling blackouts and emergency situations.

2 . We proposed a structure of integrated intelligent control system of power consumption by an enterprise. Its special feature is the integration of traditional elements of SCADA system into MES and ERP systems. Expert systems with neural network assessment of losses in active and reactive powers are used. We constructed a multilevel power consumption management system for a crushing and enrichment complex. The system performs the optimization of production during periods of limited power supply by: in- telligent power consumption management system, automated control systems for technological process, expert systems for the recognition and classification of situations by means of artificial neural systems. This distinguishes the system proposed from traditional, dispatching control systems of power consumption. A network configuration is designed for the prediction of active and reactive load in the enterprise's energy system. We defined a structure of artificial neural networks, methods of their training and the scope of their application in the system of coordinated situation management over trajectories in the production of iron ore products and power consumption by a crushing and enrichment complex. Production situations are determined for selecting rational operation modes of ball mills at an enrichment plant in the periods of limited power supply by energy system and the recognition of degree of their loads.

3. We synthesized a control of trajectory in the energy consumption by a crushing-enrichment complex with the optimization of trajectory of managing the iron ore products. A model of dependence was examined of economic criteria on such indicators as: production (consumption) of reactive power; loss of active power. Optimum loading angles of synchronous motor at a ball mill by reactive power were determined. We devised a model of optimal setpoints for exciters of synchronous motors in ball mills. Production rules are presented for the expert system to work out the fulfillment of planned production indicators over periods "peak", "half-peak", "night". In the process of imitation modeling of the developed system, we achieved a reduction in specific electricity consumption by $5-7 \%$; a decrease in losses of production in the periods of limited power supply from the energy system by $3 \%$.

\section{References}

1. Horol's'kyj, V. P. Bagatorivneva intelektual'na systema optymizacii' elektrospozhyvannjam girnycho-zbagachuval'nyh pidpryjemstv [Text] / V. P. Horol's'kyj, D. V. Horol's'kyj, K. G. Titorenko // Visnyk Hmel'nyc'kogo nacional'nogo universytetu. Tehnichni nauky. - 2015. - Issue 2. - P. 188-198.

2. Kochura, Je. V. Ekonomichnyj kryterij optymizacii' vytrat na elektroenergiju v procesah rudopidgotovky [Text] / Je. V. Kochura, A. A. Garenko // Naukovyj visnyk Nacional'nogo girnychogo universytetu. - 2011. - Issue 3. - P. 122-124.

3. Horol's'kyj, V. P. Avtomatyzovana systema upravlinnja elektrospozhyvannjam zbagachuval'noi' fabryky pidpryjemstva girnycho metalurgijnogo kompleksu [Text] / V. P. Horol's'kyj, D. V. Horol's'kyj, K. G. Titorenko // Visnyk Hmel'nyc'kogo nacional'nogo universytetu. Tehnichni nauky. - 2015. - Issue 5. - P. 86-92.

4. Energetychna strategija Ukrai'ny na period do 2030 roku [Text]. - Kabinet Ministriv Ukrai'ny. - Kyiv, 2006. - No. 145-r.

5. Shhokin, V. P. Metod korotkotryvalogo nejronechitkogo prognozu elektrospozhyvannja pidrozdilamy VAT «PivnGZK» [Text] / V. P. Shhokin, A. S. Kuz'menko, O. V. Shhokina // Praci LV MAI. - 2007. - Issue 1 (14). - P. 84-89.

6. Shchokin, V. The example of application of the developed method of Neuro-Fuzzy rationing of power consumption at JSC «YuGOK» mining enrichment plants [Text] / V. Shchokin, O. Shchokina, S. Berezhniy // Metallurgical and Mining Industry. - 2015. Issue 2. - P. 19-26. - Available at: https://www.metaljournal.com.ua/assets/Journal/english-edition/MMI_2015_2/004Bereznoi.pdf

7. Dremin, A. A. Strategija jenergosberezhenija pri dobyche i pererabotke zheleznyh rud [Text] / A. A. Dremin // Gornyj zhurnal. 2006. - Issue 12. - P. 45-47.

8. Faris Sameer Rasmi Alkhori. Automated control of oze - pebble mill charge by the signal of active power of magnetic separator electric motor [Text] / Faris Sameer Rasmi Alkhori, M. O. Alekseyev // Naukovyj visnyk Nacional'nogo girnychogo universytetu. - 2014. - Issue 3. - P. 71-76.

9. Kochura, Je. V. Ekonomiko - matematychne modeljuvannja pytomyh vytrat na elektroenergiju v procesi droblennja rudy [Text] / Je. V. Kochura, A. A. Garenko // Naukovyj visnyk Nacional'nogo girnychogo universytetu. - 2011. - P. 57-63.

10. Kornijenko, V. I. Ijerarhichne adaptyvne keruvannja procesamy rudopidgotovky za synergetychnym pryncypom z intelektual'nym prognozuvannjam [Text] / V. I. Kornijenko // Naukovyj visnyk Nacional'nogo girnychogo universytetu. - 2009. - Issue 11. P. 61-66.

11. Grigor'ev, I. V. Lokal'nye zadachi izmerenij i vychislenij pri ispol'zovanii SCADA - OASyS [Text] / I. V. Grigor'ev, I. A. Shishkov // Promyshlennye ASU i kontrollery. - 2001. - Issue 8. - P. 37-41. 
12. Hanaev, V. V. Potrebiteli - reguljatory: vozmozhnosti i perspektivy primenenija [Text] / V. V. Hanaev // Nauchno - tehnicheskie vedomosti SPbGPU. - 2008. - Issue 1. - P. 59-63.

13. Pravila ustrojstva jelektroustanovok [Text]. - 6-e izd. - Moscow: Glavgosjenergonadzor Rossii, 1998. - 608 p.

14. Stevenson, W. J. Production/Operations Management: With Standard Cd-Rom Package (Irwin/Mcgraw-Hill Series Operations and Decision Sciences) [Text] / W. J. Stevenson. - Richard D Irwin, 1998. - 912 p.

15. Khotskina, V. B. Automatization of management processes by the first stage of ore enrichment with the usage of quickly acting regressive models [Text] / V. B. Khotskina // Naukovyj visnyk Nacional'nogo girnychogo universytetu. - 2014. - Issue 3. P. $145-151$.

16. Len'shin, V. N. Proizvodstvennye ispolnitel'nye sistemy (MES) - put' k jeffektivnomu predprijatiju [Electronic resource] / V. N. Len'shin, V. V. Kuminov // Sredstva i sistemy komp’juternoj avtomatizacii. - Available at: http://asutp.ru/?p=600359

17. Kharlamov, A. A. Attention mechanism usage to form framework structures on a semantic net. Vol. 11 [Text] / A. A. Kharlamov; A. V. Holden, V. I. Krynkov (Eds.) // Neurocomputers and Attention. Connectionism and neurocomputers. - ManchesterNew York: Manchester University Press, 1991. - P. 747-756.

18. Shubladze, A. M. Sintez optimal'nyh linejnyh reguljatorov [Text] / A. M. Shubladze // Avtomatika i telemehanika. - 1984. Issue 12. - P. 22-23

В управлінні проектами ефективність роботи команди часто пов'язують з ї балансуванням в термінах командних ролей. Для розуміння закономірностей переходів учасників команди між командними ролями запропоновано використовувати апарат ланцюгів Маркова. За допомогою моделювання виконано дослідження $і$ показано, що для команди проекту з розробки програмного забезпечення природним є прагнення збалансувати командні ролі

Ключові слова: управління проектами, формування команди проекту, командні ролі Белбіна, ланцюги Маркова

В управлении проектами эффективность работы команды часто связывают с ее балансированием в терминах командных ролей. Для понимания закономерностей переходов участников команды между командными ролями предложено использовать аппарат цепей Маркова. С помощью моделирования выполнено исследование и показано, что для команды проекта по разработке программного обеспечения естественным является стремление сбалансировать командные роли

Ключевые слова: управление проектами, формирование команды проекта, командные роли Белбина, цепи Маркова
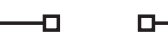

\section{Introduction}

Team development in software engineering requires the application of team-oriented methods for project management. Team roles are an important factor that affects the success of projects in the field of software engineering [1].

One of the practical tools for a project manager when forming a team is the analysis of the Belbin's team roles, who in his work tried to answer the question on why projects are successful or unsuccessful [2]. He demonstrated that effective work of a team is connected to its balance in terms
UDC 005.32

DOI: $10.15587 / 1729-4061.2017 .91597$

EXAMINING THE ATTRIBUTES OF TRANSITIONS BETWEEN TEAM ROLES IN THE SOFTWARE DEVELOPMENT PROJECTS

V. Li u b c he n ko

Doctor of Technical Sciences, Associate Professor Department of System Software*

E-mail: Ivv@edu.opu.ua

I. S u I i mova

Head of laboratory

Training and production laboratory "Modern business technologies" of the Center of Partnership with Enterprises*

E-mail: julia.sulimova@gmail.com *Odessa National Polytechnic University Shevchenko ave., 1, Odessa, Ukraine, 65044 of team roles of members of the team. Although the original work dealt with the overall project management, it was demonstrated [3] that it is relevant, in particular, for the area of software engineering.

In general, observing the behavior of representatives of particular team roles made it possible to identify strong and weak features of each of the roles, as well as general patterns of interactions between roles. All this is of significant interest for the field of software engineering. Taking into account the peculiarities of separate team roles, both at the stage of forming and in the process of work, allows overcoming the 